\title{
Effect of Selected Leguminous Cover Crop Species on the Productivity of Coconut Cultivated in Reddish Brown Latosolic Soils in Sri Lanka
}

\author{
S. H. S. Senarathne* , S. S. Udumann
}

\begin{abstract}
This study was conducted for six years to assess the effects of two widely grown cover crops Gliricidia sepium $\left(\mathrm{T}_{1}\right)$ and Puereria phasioloides $\left(\mathrm{T}_{2}\right)$ on coconut yields and soil characteristics. Experiments were carried out on coconuts planted in Reddish Brown Latosolic soils located in the low country intermediate zone-IL1 of Sri Lanka. Results showed that treatments 1 and 2 were significantly $(p \leq 0.05)$ effective over the control treatment (no cover $c r o p)$ in suppressing weed biomass. Soil samples were collected and analyzed for physical, chemical and biological properties. Results showed that soils where G. sepium and P. phasioloides were grown were superior in most of the properties compared to the control. Soils under P. phasioloides showed significantly higher moisture contents compared to G. sepium and control treatments. Significant increases on soil properties were likewise observed in G. sepium and P. phasioloides plots: nitrogen (by 77\% and $76 \%$ ), organic carbon content (by $86 \%$ and $148 \%$ ), soil microbial activity (by $52 \%$ and $73 \%$ ), respectively. On the other hand, soil bulk densities were reduced significantly by $20 \%$ and $27 \%$ under G. sepium and $P$. phasioloides, respectively. There was no significant increase observed on available P but $\mathrm{P}$ content improved with the establishment of cover crops. Significant increases in mean annual nut yields were observed during the $4^{\text {th }}, 5^{\text {th }}$, and $6^{\text {th }}$ years after cover crops establishment. Nut yields were found to increase with G. sepium and P. phasioloides by $46 \%$ and $58 \%$, respectively when compared to that of control treatment plots.
\end{abstract}

Key words: Gliricidia, Pueraria, coconut, cover crops, soil amendment

\section{INTRODUCTION}

The coconut (Cocos nucifera) contributes to the livelihoods of millions of people in the developing world, not only through its production but also through employment generated by the many associated industries. It is the most widespread, economically useful palm of the wet tropics. Coconut is ideally grown under tropical climatic conditions. The degradation and loss of organic matter from soils under tropical climatic conditions is high due to optimal temperature, porous, light textured soil types and high precipitation. The growth habit of the coconut palm and the canopy structure requires a wide spacing between palms which permits the penetration of abundant sunlight to the ground vegetation. Thus, a wide range of perennial and annual weed species often invade the unutilized space beneath coconut palms (Senarathne et al., 2003). However, this space can be utilized to grow beneficial plant species depending on a particular purpose the farmer wants.

\footnotetext{
${ }^{1}$ Agronomy Division, Coconut Research Institute, Lunuwila, Sri Lanka.

*Corresponding Author: shsumith71@yahoo.com
} 
Establishment of different leguminous cover crops in unutilized space between coconut palms helps to minimize surface run-off during heavy rains thereby controlling soil erosion. Cover crops also provide large quantities of mulch that help improve organic matter content in the soil. Penetration of leguminous cover crop roots into the soil improves the soil structure, improves infiltration of water, reduces leaching of nutrients, reduces ground surface temperature, controls the growth of weeds and provides nitrogen to the soil (Liyanage and Dasanayake, 1993). Leguminous cover crops are considered green manure, hence their cultivation in situ and their incorporation were considered to be a viable alternative to inorganic fertilization. This was practiced by the farmers as it is the most convenient and economically viable method for enhancing the organic matter status in the soil. Growing of green manuring crops improves the soil structure and nutrient status in the soil. In addition, they aid in releasing plant nutrients, reducing leaching, regulating soil temperatures, and enhances the activities of soil microbes. Several plant species have been tested as a cover crop in coconut plantations in the past. However, the suitability of a cover crop in coconut plantation depends on the climatic and soil characteristics in a particular growing area. Major cover crops recommended for coconut lands in Sri Lanka are, Pueraria phaseoloides, Calopogonium mucunoides, Centrosema pubescens and bush cover crops such as Gliricidia sepium (Coconut Research Institute, 2012). These cover crops produce large amount of green biomass and litter. These green biomass can be used as a green manure for coconut palms.

The application of green manure materials such as tree or shrub pruning with relatively high nutrient composition and fast decomposition properties have been recommended either as sole soil amendment or in combination with mineral fertilizers (Gachengo et al., 1999; Nziguheba et al., 2000 and Quinkenstein et al., 2009). The addition of these tree or shrub prunings through alley cropping or biomass transfer systems had made substantial contribution to the development of sustainable land use systems in the tropics by providing a cost effective mechanism for optimizing crop yields for efficient and stable crop production (Kang 1997 and Young 1997). The periodic pruning and return of biomass from hedgerow trees or shrubs through alley cropping or biomass transfer, contribute to recycling of plant nutrients, improvements in soil temperature, enhancement of soil structure, erosion control, and maintenance of microbial activity and high soil nutrient status (Isaac et al., 2003; Lin et al., 2009 and Wang et al., 2010). Moreover, long term productivity of alley cropping or biomass transfer systems requires shrubs or tree species that can coppice vigorously after each cutting (Latt et al., 2000). With many of the soil fertility and nutrient cycling benefits of agroforestry systems derived from the production and decomposition of tree biomass (Nair et al., 1999), optimal biomass production would be expected at each cutting to provide sufficient amounts of nutrients to crop nutrient demands (Latt et al., 2000). Some areas of the intermediate zone of Sri Lanka are characterized by the presence of Reddish Brown Latasolic soils. Since soil fertility of this soil group is comparatively much lower to its counterpart the Reddish Brown Earth soil. However, the impact of different leguminous cover crops as mulch or incorporated on soil development and the subsequent productivity of coconut palms in Reddish Brown Latasolic soils has not been clearly identified especially in field studies on coconut farming systems. The objectives of this study were to monitor the long term effects of leguminous cover crop establishment in coconut plantations for its land productivity in Reddish Brown Latasolic soils in the region.

\section{MATERIALS AND METHODS}

This experiment was carried out at the Ridigama Estate, Dodangaslanda, in the Low 
country Intermediate Zone of North Western Province of Sri Lanka for six years, from January 2007 to December 2012. The area is characterized by bi-modal pattern of rainfall with an annual mean precipitation of $1500 \mathrm{~mm}$. Approximately $65 \%$ of the annual rainfall is received from September to February (Maha). There is a smaller peak of rainfall from March to May (Yala), but the rainfall is erratic. Higher ambient air and soil temperatures (about $28^{\circ} \mathrm{C}$ $32^{\circ} \mathrm{C}$ ) and bright sunshine hours (about $6-8$ hours per day) are more common especially during the dry periods from May to September. The soil at the site is a Reddish Brown Latasolic (RBL) (USDA soil taxonomy - Rhodudalfs fine loamy, non-calcareous, isohyperthermic), (FAO/ UNESCO soil taxonomy - RhodicCutanicLuvisols). Soils are very deep and well drained. Surface soil is dark brown in colour with a sandy clay loam texture. The sub surface soil is dark reddish brown to dark red in colour with a texture that ranges from clay loam to clay. The structure of the sub surface soil is moderately developed coarse sub angular blocky with patchy cutans on ped faces. However, during the dry season; the ground water table remains at $10-12 \mathrm{~m}$ below the ground surface. Reaction of the soil is slightly acidic (pH 6.0 - 6.5) throughout the soil profile (Mapa et al., 2005).

\section{Treatments}

$\mathrm{T}_{1}$ - Establishment of Gliricidia sepium under coconut

$\mathrm{T}_{2}$ - Establishment of Pueraria phaseoloides under coconut

$\mathrm{T}_{3}$ - Control

\section{Establishment of the experiment}

One bush type (Gliricidia sepium) and one creeping (Pueraria phaseoloides) leguminous cover crops were selected for this experiment. Age of the coconut plantation was 50 years and trees were planted at a spacing of $8 \mathrm{~m} \times 8 \mathrm{~m}$ (giving a density of 137 trees/ha). The cuttings of Gliricidia and Pueraria seeds were established during the 2007 rainy season. Three feet long well matured Gliricidia sticks were used for planting the trials. Double rows of Gliricidia cuttings were planted in between two rows of coconut palms, at a spacing of $1 \mathrm{~m} \times 2 \mathrm{~m}$ (2250 cuttings ha $\left.^{-1}\right)$. The distance between coconut palms and Gliricidia was 3 meters. Each experimental plot was $384 \mathrm{~m}^{2}$ (consisting of six coconut squares) in size and plots were separated by a single row of coconut. The Pueraria phaseoloides cover crop was established in the harrowed plots at a seeding rate of $5 \mathrm{~kg}$ ha-1. Overgrown conditions of the cover crop were managed to overcome competition by tractor harrowing twice a year and excess biomass was thatched around the coconut palms.

Experimental treatments were arranged in a Complete Randomized Block Design with three replicates. Gliricida plants were left to grow during the first 18 months without pruning. The first pruning was done on May 2009. Threafter, all the coppiced sprouts were cut back to within $4 \mathrm{~cm}$ of the stump. This was done two times per year at the onset of monsoon rains. Pruned green biomass was thatched as a mulch around the coconut plams. This kind of management allowed the establishment of a vigorous stand of Gliricidia.

Before starting the experiment, all the coconut palms were fertilized each with $3 \mathrm{~kg}$ of fertilizer mixture (800g Urea, 600g Rock Phosphate and 1600g Muriate of Potash) with $1000 \mathrm{~g}$ of Dolomite/palm/year. Fertilizer applications were carried out as per the recommendations given by the Coconut Research Institute of Sri Lanka.

\section{Collection of ground cover weed biomass}

The ground cover weed biomass was collected once in every month using $1 \mathrm{~m} \times 1 \mathrm{~m}$ 
quadrates from four random points per plot. Plant biomass samples were dried at $80^{\circ} \mathrm{C}$ for five days until it reached to a constant weight and dry weight was recorded.

\section{Soil sampling and analysis}

From the commencement of the experiment, soil samples were randomly collected $2.5 \mathrm{~m}$ away from the effective root zone of coconut palms and at $0-30 \mathrm{~cm}$ depth for determination of available and exchangeable plant nutrients in the soil. Simultaneously, an undisturbed soil sample was also collected using a core-sampler at depths of $0-15 \mathrm{~cm}$ and $15-30 \mathrm{~cm}$ for the determination of bulk density. Samples were processed under laboratory conditions by air drying separately at room temperature for 48-72 hours without any contaminations. Air dried soil samples were crushed and sieved through $2 \mathrm{~mm}$ sieve. In addition, undisturbed soil samples were collected from same locations to determine microbial activity. For physiochemical characterization, the following soil parameters were determined: organic carbon of the samples were measured by WalkeyBlack method (Walkley and Black, 1934); N was estimated by the Kjeldahl method (Jackson, 1973) and the P and K contents of the samples were analyzed by calorimetric method (Anderson and Ingram, 1993) and flame photometric method (Simard, 1993), respectively. For the soil biological property, microbial activity was determined by trapping $\mathrm{CO}_{2}$ with alkali solutions, followed by the precipitation of carbonates with barium chloride, and the titration of any remaining hydroxide with standardised acid (Stotzky, 1965).

\section{Determination of soil moisture content}

Soil samples were collected from four random points that were $2.5 \mathrm{~m}$ away from the effective coconut palms and at a $30 \mathrm{~cm}$ depth to determine the treatment effect on soil moisture content during drier months (January and July). These soil samples were oven dried at $105^{\circ} \mathrm{C}$ until constant weight is attained and gravimetric soil moisture content was determined afterwards.

\section{Data analysis}

Experimental data were analysed following the Analysis of Variance (ANOVA) procedure using the statistical software SAS and the significance of the differences between means was tested using the Least Significant Differences (LSD) at a P0.05 Value (SAS Institute 1999).

\section{RESULTS AND DISCUSSION}

\section{Effect of treatments in controlling ground cover weed biomass}

The lowest weed biomass was recorded in Pueraria phaseoloides established treatment plots (Figure 1). Initially P. phaseoloides took several months to establish a good cover. The weed biomass was very high at initial stages in cover cropped treatments plots but declined gradually later. When Pueraria was established, the weed biomass was reduced but weed seeds in the soil seed bank initiated germination with the onset of rainy season. Most of the new emerging weeds were annual dicotyledonous species (Allmania nodiflora, Mitracarpus villosus, Tephrosia purpurea, Vernonia cinerea). The emergence of monocotyledonous (Panicum maximum, Pennisetum polystachion, Imperata cylindrica) weed species was comparatively low. $P$. phaseoloides became self-seeded, and formed a good ground cover a few months after sowing, thereby suppressing weed populations by $90 \%$ (Figure 1). However, management of cover crops was essential to avoid possible competition between coconut palms and cover crops. Planting Gliricidia sepium between coconut rows was found to be a less effective method of controlling weeds in coconut plantations (Figure 1). However, G. sepium grows rapidly producing 


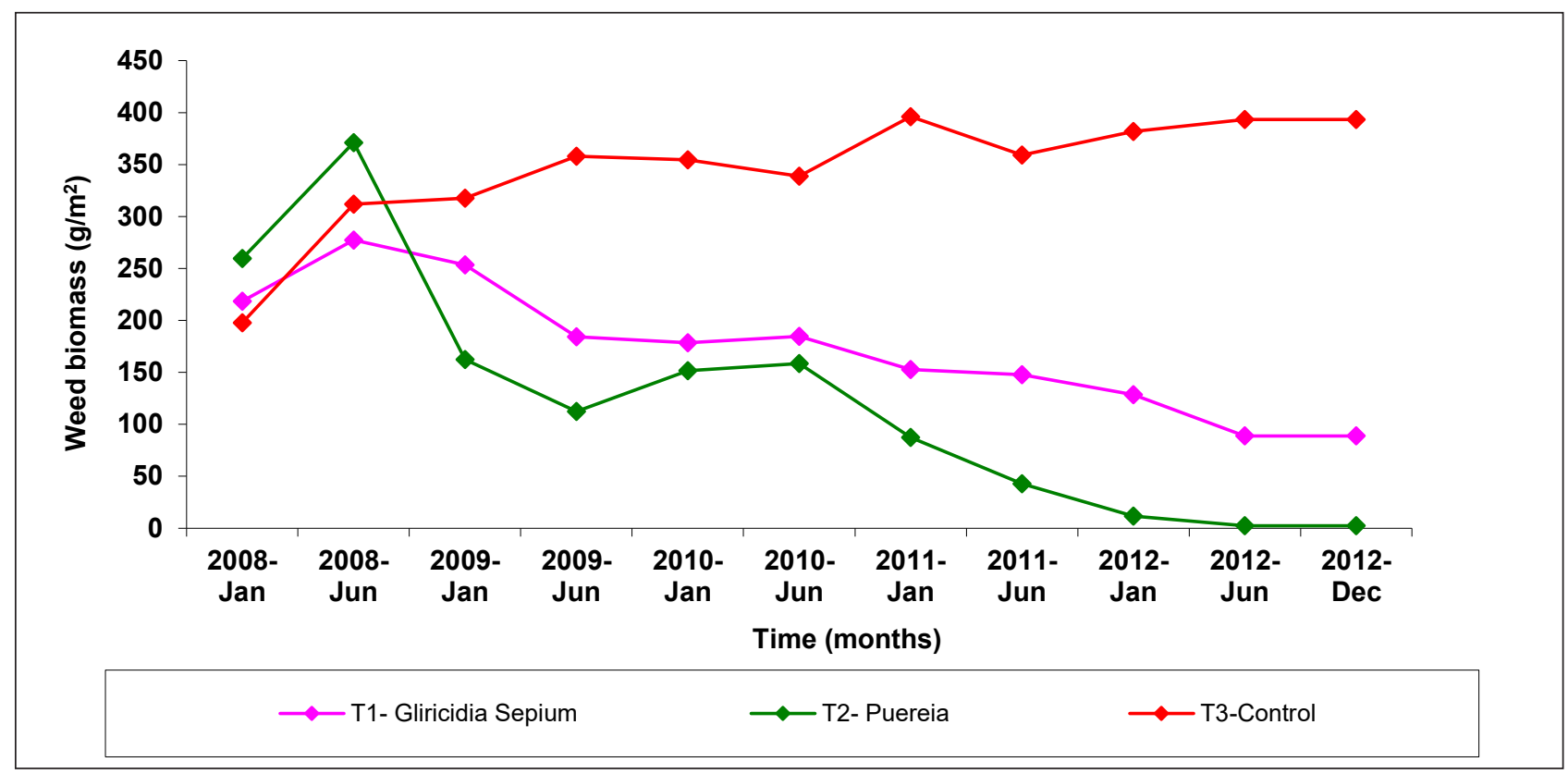

Figure 1. Effect of treatments on total weed biomass from January 2008 to December 2012

large quantities of foliage which can be used as mulch around the coconut palms thereby aiding in the control of weed population (Senarathne and Sangakkara, 2009).

\section{Effect of treatments on soil physical properties (soil moisture and bulk density)}

During the experimental period, results indicated that the moisture content significantly differ during the last three years (2010-2012) of experimental period (Table 1). However, cover crops established treatments have shown a quantitatively higher soil moisture compared

\begin{tabular}{lccccc}
\hline \multirow{2}{*}{ Treatments } & \multicolumn{5}{c}{ Soil moistures content (\%) } \\
\cline { 2 - 6 } & 2008 & 2009 & 2010 & 2011 & 2012 \\
\hline $\begin{array}{l}\mathrm{T}_{1} \text { - Gliricidia } \\
\text { sepium }\end{array}$ & 2.76 & 3.62 & 1.44 & 4.56 & 2.98 \\
$\begin{array}{l}\mathrm{T}_{2} \text { - Pueraria } \\
\text { phaseoloides }\end{array}$ & 3.14 & 4.12 & 3.27 & 6.78 & 5.68 \\
$\mathrm{~T}_{3}$ - Control & 3.15 & 3.13 & 1.27 & 2.98 & 1.58 \\
Significance & $\mathrm{ns}$ & $\mathrm{ns}$ & $*$ & $*$ & $*$ \\
LSD (P<0.05) & - & - & 1.21 & 2.82 & 2.15 \\
\hline
\end{tabular}

* Significantly different at $\mathrm{P}=0.05$; ns - not significant

Table 1. Effect of treatments on soil moisture content $(\%)$ to the control treatment. Areas planted to P. Phaseeoloides cover crop had a comparatively higher soil moisture content during the whole experimental period.

However, although P. phaseoloides covered soils were found to be quantitatively higher in soil moisture content, their differences were found to be significant $(\mathrm{P}<0.05)$ only during the last three years (2010-2012) of the experimental period (Table 1). The control showed the lowest soil moisture content during the whole experimental period, except in 2008.

These increases in soil moisture contents might be due to the contribution of cover crop plant biomass litter to the soil surface which might have improved the soil's physical properties. Ji and Under (2001) reported that higher organic carbon contents of the soil increases its water holding capacity. Soil organic matter is responsible to a great extent, directly or indirectly for a good physical soil environment making it suitable for the plant root growth (Jeyamala and Soman, 1999). There is also a body of evidence that supports the ability of cover crops to increase soil carbon or soil organic 
matter ( McDaniel et al., 2014, Moore et al., 2014 and Poeplau and Don, 2015) and to improve the soil physical properties which enhance soil water dynamics (Daigh et al., 2014a, Steele et al., 2012 and Villamil et al., 2006). Furthermore, there is a complex interaction of soil physical and chemical properties that contribute to soil water storage capacity, including soil organic matter concentration, aggregation and porosity (Emerson, 1995; Hudson, 1994 and Kay, 1998).

The establishment of cover crops was found to reduce the bulk density of soil (Table 2) compared to the control treatment. Bulk density is a vital soil characteristic for successful root development (Kuchenbuch and Ingram, 2004). There was no significant difference in the bulk density in $\mathrm{T}_{1}$ and $\mathrm{T}_{2}$ during the first two years. However, significant effects were observed in soil bulk densities three years after treatment. Soils in G. sepium and P. phaseoloides were found to be lesser in bulk densities compared to control. The lowest bulk density was observed in $\mathrm{T}_{2}$ during the last three years of the experimental period. Accumulated organic matter from litters of covercrops during the first three years and the succeeding years increases the organic matter of the soil. A high level of organic matter in the soil indicates reduced bulk density, improved soil structure, better aeration and highwater holding capacity all of which are attributes of a productive soil (Hseih and Hseih, 1990).

\begin{tabular}{lccccc}
\hline \multirow{2}{*}{ Treatments } & \multicolumn{5}{c}{ Soil bulk density $\left(\mathrm{g} / \mathrm{cm}^{3}\right)$} \\
\cline { 2 - 6 } & 2008 & 2009 & 2010 & 2011 & 2012 \\
\hline $\begin{array}{l}\mathrm{T}_{1} \text { - Gliricidia } \\
\text { sepium }\end{array}$ & 1.63 & 1.58 & 1.49 & 1.42 & 1.36 \\
$\begin{array}{l}\mathrm{T}_{2} \text { - Pueraria } \\
\text { phaseoloides }\end{array}$ & 1.72 & 1.48 & 1.36 & 1.32 & 1.24 \\
$\mathrm{~T}_{3}$ - Control & 1.71 & 1.64 & 1.68 & 1.73 & 1.69 \\
Significance & $\mathrm{ns}$ & $\mathrm{ns}$ & $*$ & $*$ & $*$ \\
LSD (P<0.05) & - & - & 0.15 & 0.21 & 0.24 \\
\hline$*$ Significantly different & & & & & \\
\hline
\end{tabular}

Table 2. Effect of treatments on soil bulk density $\left(\mathrm{g} / \mathrm{cm}^{3}\right)$

\section{Effect of treatments on soil biological properties (microbial activity)}

Significant effect of treatments on soil microbial activity were observed during the last four years of the experimental period (Table $3)$. The highest soil microbial activities were recorded in coconut areas with covercrops $\left(\mathrm{T}_{1}\right.$ and $\mathrm{T}_{2}$ ). The lowest soil microbial activity was observed in control treatment $\left(\mathrm{T}_{3}\right)$ during the whole period of the experiment (Table 3).

\begin{tabular}{lccccc}
\hline \multirow{2}{*}{ Treatments } & \multicolumn{5}{c}{ Microbial activity (mg/day) } \\
\cline { 2 - 6 } & 2008 & 2009 & 2010 & 2011 & 2012 \\
\hline $\begin{array}{l}\mathrm{T}_{1} \text { - Gliricidia } \\
\text { sepium }\end{array}$ & 77.5 & 91.9 & 109.8 & 116.2 & 116.4 \\
$\begin{array}{l}\mathrm{T}_{2} \text { - Pueraria } \\
\text { phaseoloides }\end{array}$ & 76.2 & 98.1 & 123.9 & 118.6 & 132.4 \\
$\mathrm{~T}_{3}$ - Control & 71.5 & 74.7 & 68.3 & 84.5 & 76.4 \\
Significance & $\mathrm{ns}$ & $*$ & $*$ & $*$ & $*$ \\
LSD (P<0.05) & - & 14.8 & 23.2 & 12.8 & 22.3 \\
\hline
\end{tabular}

* Significantly different at $\mathrm{P}=0.05$; ns - not significant

Table 3. Effect of treatments on soil microbial activity (mg/day)

The establishment of cover crops is considered as a good management practice as it stimulates soil microbial growth and activity. Subsequent mineralization of plant nutrients (Eriksen, 2005) increases soil fertility and quality (Doran et al., 1988). Likewise, cover crops provide active living roots that form symbiotic relationships with fungi. These relationships are crucial in building a healthy soil. Different types of mycorrhizal fungi can be found on almost $90 \%$ of all plants in the world (Steenwerth and Belina, 2008). Other factors that may had contributed to the increased microbial activities were the abundance of organic matter due to litters, reduced ground surface temperature, and increased soil moisture creating a microclimate suitable for microbial growth. 


\section{Effects of treatments on soil chemical properties (organic $\mathrm{C}$, available $\mathrm{P}$, total $\mathrm{N}$ and exchangeable $\mathrm{K}$ )}

The establishment of selected leguminous cover crops had no significant impact on available phosphorus content in the soil during the whole experimental period (Table 4). The available $\mathrm{P}$, however, was observed to gradually increases throughout the experimental period, with $P$. phaseoloides treatment exhibiting the highest gain.

\begin{tabular}{lccccc}
\hline \multirow{2}{*}{ Treatments } & \multicolumn{5}{c}{ Soil P (ppm) } \\
\cline { 2 - 6 } & 2008 & 2009 & 2010 & 2011 & 2012 \\
\hline $\begin{array}{l}\mathrm{T}_{1} \text { - Gliricidia } \\
\text { sepium }\end{array}$ & 11.32 & 12.41 & 13.42 & 14.94 & 15.34 \\
$\begin{array}{l}\mathrm{T}_{2} \text { - Pueraria } \\
\text { phaseoloides }\end{array}$ & 10.11 & 16.32 & 15.88 & 16.28 & 16.95 \\
$\mathrm{~T}_{3}$ - Control & 11.45 & 10.98 & 11.48 & 12.85 & 12.01 \\
Significance & $\mathrm{ns}$ & $\mathrm{ns}$ & $\mathrm{ns}$ & $\mathrm{ns}$ & $\mathrm{ns}$ \\
LSD (P<0.05) & - & - & - & - & - \\
\hline
\end{tabular}

* Significantly different at $\mathrm{P}=0.05$; ns - not significant

Table 4. Effect of treatments on soil available P (ppm) content

Available $\mathrm{N}$ and $\mathrm{K}$ in the soil were shown to be significantly higher compared to control (Table 5 and 6). From 2010 to 2012, N contents in $\mathrm{T}_{1}$ and $\mathrm{T}_{2}$ are comparatively higher than $\mathrm{T}_{3}$ (Table 5). Leguminous cover crops are known to improve the nutrient availability in the soil (Seiter and Horwath, 2004). The mean increments in soil $\mathrm{N}$ due to the establishment of leguminous cover crops (G. sepium and P. phaseoloides) were $76.5 \%$ and $75.6 \%$ respectively compared to the control. Both leguminous cover crops increased the total $\mathrm{N}$ content of the soil (Table 5). Leguminous plants improve soil $\mathrm{N}$ by returning $\mathrm{N}$-rich organic litter to the soil, which may help maintain soil $\mathrm{N}$ pools in tropical soils (Hedin et al., 2009). Soil nitrogen plays an important role in improving the productivity and sustainability of farms. Similar effect can also be observed with the use of high quality organic manures (i.e. organic manures with low C: N ratio) (Six et al., 2002). In tropical regions, however, the combination of low availability of organic carbon and nitrogen leads to poor-quality soil and low sustainability (Egodawatta et al., 2012).

\begin{tabular}{lccccc}
\hline \multirow{2}{*}{ Treatments } & \multicolumn{5}{c}{ Soil N (ppm) } \\
\cline { 2 - 6 } & 2008 & 2009 & 2010 & 2011 & 2012 \\
\hline $\begin{array}{l}\mathrm{T}_{1} \text { - Gliricidia } \\
\text { sepium }\end{array}$ & 287.2 & 324.4 & 332.4 & 495.0 & 581.7 \\
$\begin{array}{l}\mathrm{T}_{2} \text { - Pueraria } \\
\text { phaseoloides }\end{array}$ & 292.5 & 328.4 & 324.8 & 505.2 & 578.9 \\
$\mathrm{~T}_{3}$ - Control & 311.8 & 315.7 & 265.2 & 322.1 & 329.1 \\
Significance & $\mathrm{ns}$ & $\mathrm{ns}$ & $*$ & $*$ & $*$ \\
LSD (P<0.05) & - & - & 22.7 & 39.7 & 29.4 \\
\hline
\end{tabular}

* Significantly different at $\mathrm{P}=0.05$; ns - not significant

Table 5. Effect of treatments on soil total N (ppm) content

A similar trend was observed with the effects of the treatments to the availability of exchangeable $\mathrm{K}$ content in the soil. Mean value of soil K were enhanced by $190 \%$ and $150 \%$ in $\mathrm{T}_{1}$ and $\mathrm{T}_{2}$, respectively (Table 6 ). Higher exchangeable $\mathrm{K}$ contents were recorded in $\mathrm{T}_{1}$ and $\mathrm{T}_{2}$ compared to the control $\left(\mathrm{T}_{3}\right)$. The lowest exchangeable $\mathrm{K}$ content was observed in the control treatment during the whole experiment. Results clearly show the importance of establishing cover crops for improving soil quality and fertility.

\begin{tabular}{lccccc}
\hline \multirow{2}{*}{ Treatments } & \multicolumn{5}{c}{ Soil K (meq/100g) } \\
\cline { 2 - 6 } & 2008 & 2009 & 2010 & 2011 & 2012 \\
\hline $\begin{array}{l}\mathrm{T}_{1} \text { - Gliricidia } \\
\text { sepium }\end{array}$ & 0.068 & 0.082 & 0.108 & 0.116 & 0.296 \\
$\begin{array}{l}\mathrm{T}_{2} \text { - Pueraria } \\
\text { phaseoloides }\end{array}$ & 0.065 & 0.091 & 0.115 & 0.118 & 0.256 \\
$\mathrm{~T}_{3}$ - Control & 0.061 & 0.077 & 0.091 & 0.087 & 0.102 \\
Significance & $\mathrm{ns}$ & $\mathrm{ns}$ & $*$ & $*$ & $*$ \\
LSD (P<0.05) & - & - & 0.009 & 0.022 & 0.124 \\
\hline
\end{tabular}

* Significantly different at $\mathrm{P}=0.05$; ns - not significant

Table 6. Effect of treatments on soil exchangeable K (meq/100g) 


\section{Effect of selected leguminous cover crops on soil organic C content (\%)}

Results in Table 7 indicate increased soil organic carbon contents in $\mathrm{T}_{1}$ and $\mathrm{T}_{2}$. There was a significant effect of treatments on soil organic C content during the last three years of the experimental period (Table 7). The highest soil organic $\mathrm{C}$ content was recorded in $\mathrm{T}_{2}$ while the lowest was recorded in $\mathrm{T}_{3}$. Similar results were observed by Follett et al., (2007). Past studies showed that the addition of organic residues increases the soil organic carbon level initially. However, it gradually decreases in the soil up to a certain period (Gulser et al., 2010 and Manivannan et al., 2009). Incorporation of legume residues is really useful to the soil for growing soil natural carbon awareness which is not only vital to agricultural productiveness but also to sequestration of $\mathrm{C}$ from atmospheric $\mathrm{CO}_{2}$ (Ayarza et al., 2007). When leguminous cover crops are used as green manure and incorporated into the soil, their residues enhance the availability of N, P, $\mathrm{K}$, and trace elements to the succeeding plants due to the lowering of the soil $\mathrm{pH}$ brought about by the $\mathrm{CO}_{2}$ produced in the process of decomposition (Benchaar et al., 2001).

\begin{tabular}{lccccc}
\hline \multirow{2}{*}{ Treatments } & \multicolumn{5}{c}{ Soil organic C (\%) } \\
\cline { 2 - 6 } & 2008 & 2009 & 2010 & 2011 & 2012 \\
\hline $\begin{array}{l}\mathrm{T}_{1} \text { - Gliricidia } \\
\text { sepium }\end{array}$ & 1.08 & 1.18 & 1.38 & 1.78 & 1.98 \\
$\begin{array}{l}\mathrm{T}_{2} \text { - Pueraria } \\
\text { phaseoloides }\end{array}$ & 1.14 & 1.56 & 2.11 & 2.46 & 2.63 \\
$\mathrm{~T}_{3}$ - Control & 1.04 & 1.12 & 1.09 & 1.11 & 1.06 \\
Significance & $\mathrm{ns}$ & $\mathrm{ns}$ & $*$ & $*$ & $*$ \\
LSD (P<0.05) & - & - & 0.94 & 1.02 & 1.14 \\
\hline * Significantly different at $\mathrm{P}=0.05 ; \mathrm{ns}-$ not significant
\end{tabular}

Table 7. Effect of selected leguminous cover crops on soil organic C content (\%) Effect of the treatments on coconut yield
(nuts/palm/year)

Results show that the establishment of leguminous cover crops increases nut yields.

Significant effects on nut yields were observed during the last three years of the experimental period in coconuts palms with $P$. phaseoloides cover crop (Table 8). Although there was an increase in yield of palms with $G$. sepium covercrop, the difference was insignificant compared with the control. Cover crops should be viewed as a long-term investment that gradually improves farm management in multiple areas, for altering soil physical, chemical or biological properties, to minimize erosion, or to improve soil fertility. While it has been long known that cover crops can influence soil properties (Masiunas, 1998). The yield benefits were likely due to soil nutrient credits provided from the mineralization of cover crop biomass prior to or during the crop production (Belfry et al., 2017). Further, the tomato yield benefits with vs. without cover crops in the crop rotation after 6- years were linked to 8.4-9.3\% greater surface soil organic carbon concentrations (Chahal and Van Eerd, 2018). Decreased weed abundance might also contribute to yield benefits, as cover crop mulches may provide a physical barrier to weed growth and thereby improve vegetable crop production (Altieri et al., 2011). Thus, cover crops may benefit multiple soil health functions such as carbon sequestration, mitigating nutrient losses and supporting crop production (Chahal and Van Eerd, 2018).

\begin{tabular}{lcccccc}
\hline & \multicolumn{6}{c}{ Nuts/palm/year } \\
\cline { 2 - 7 } Treatments & 2007 & 2008 & 2009 & 2010 & 2011 & 2012 \\
\hline $\begin{array}{l}\mathrm{T}_{1} \text { - Gliricidia } \\
\text { sepium }\end{array}$ & 45 & 53 & 53 & 33 & 68 & 63 \\
$\begin{array}{l}\mathrm{T}_{2} \text { - Pueraria } \\
\text { phaseoloides }\end{array}$ & 36 & 42 & 51 & 42 & 71 & 68 \\
$\begin{array}{l}\mathrm{T}_{3} \text { - Control } \\
\text { (APM) }\end{array}$ & 45 & 50 & 43 & 32 & 42 & 43 \\
$\begin{array}{l}\text { Significance } \\
\text { LSD (P<0.05) }\end{array}$ & ns & ns & ns & $*$ & $*$ & $*$ \\
\hline & - & - & 8 & 14 & 11 \\
\hline
\end{tabular}




\section{CONCLUSION}

This study highlighted the importance of cover crop establishment for coconut farming systems. It demonstrated the possibility of in situ cultivation of two different leguminous cover crops (G. sepium and P. phaseoloides) in coconut plantations and their effect on increasing organic matter content of the soil which ultimately adds nutrients to the soil besides improving soil physical and chemical properties. P. phaseoloides is the most effective cover crop for managing the ground surface between coconut palms. Cover crops also stimulated soil biological activities which is necessary for soil health and fertility. The results also showed a positive effect on coconut yield and are environmentally friendly and economical. Based on the results of the study, it can be concluded that the use of in situ cover cropping system based green manures along with chemical fertilizers, is important for increasing soil productivity in coconut plantations established in Reddish Brown Latasolic soils in Sri Lanka.

\section{REFERENCES}

Anderson, J. M., \& Ingram, J. S. I. (Eds.). (1989). Tropical soil biology and fertility (p. 221). A Handbook of Methods $2^{\text {nd }}$ ed. Wallingford: CAB international.

Ayarza, M., Amézquita, E., Rao, I., Barrios, E., Rondón, M., Rubiano, Y., \& Quintero, M. (2007). Advances in improving agricultural profitability and overcoming land degradation in savanna and hillside agroecosystems of tropical America. In Advances in integrated soil fertility management in sub-Saharan Africa: challenges and opportunities (pp. 209229). Springer, Dordrecht.

Belfry, K. D., Trueman, C., Vyn, R. J., Loewen, S. A., \& Van Eerd, L. L. (2017). Winter cover crops on processing tomato yield, quality, pest pressure, nitrogen availability, and profit margins. PloS one, 12(7), e0180500.

Benchaar, C., Pomar, C., \& Chiquette, J. (2001). Evaluation of dietary strategies to reduce methane production in ruminants: a modelling approach. Canadian Journal of Animal Science, 81(4), 563-574.

Chahal, I., \& Van Eerd, L. L. (2018). Evaluation of commercial soil health tests using a medium-term cover crop experiment in a humid, temperate climate. Plant and Soil, 427(1), 351-367.

Coconut Research Institute 2012. Cover crops in coconut land. Available from: http://www. cri.gov.lk/. (Accessed: 19 January 2014).

Daigh, A. L., Zhou, X., Helmers, M. J., Pederson, C. H., Ewing, R., \& Horton, R. (2014). Subsurface drainage flow and soil water dynamics of reconstructed prairies and corn rotations for biofuel production. Vadose Zone Journal, 13(4).

Doran, J. W., Fraser, D. G., Culik, M. N., \& Liebhardt, W. C. (1987). Influence of alternative and conventional agricultural management on soil microbial processes and nitrogen availability. american Journal of alternative agriculture, 2(3), 99-106.

Egodawatta, W. C. P., Sangakkara, U. R., \& Stamp, P. (2012). Impact of green manure and mineral fertilizer inputs on soil organic matter and crop productivity in a sloping landscape of Sri Lanka. Field Crops Research, 129, 21-27.

Emerson, W. W. (1995). Water-retention, organic-C and soil texture. Soil Research, 33(2), 241-251.

Eriksen, J. (2005). Gross sulphur mineralisationimmobilisation turnover in soil amended 
with plant residues. Soil biology and Biochemistry, 37(12), 2216-2224.

Follett, R. F., Paul, E. A., \& Pruessner, E. G. (2007). Soil carbon dynamics during a longterm incubation study involving $13 \mathrm{C}$ and 14C measurements. Soil Science, 172(3), 189-208.

Gachengo, C. N., Palm, C. A., Jama, B., \& Othieno, C. (1998). Tithonia and senna green manures and inorganic fertilizers as phosphorus sources for maize in Western Kenya. Agroforestry systems, 44(1), 21-35.

Gulser, C., Demir, Z., \& Ic, S. (2010). Changes in some soil properties at different incubation periods after tobacco waste application. Journal of Environmental Biology, 31(5), 671-674.

Hedin, L. O., Brookshire, E. J., Menge, D. N., \& Barron, A. R. (2009). The nitrogen paradox in tropical forest ecosystems. Annual Review of Ecology, Evolution, and Systematics, 40, 613-635.

Hsieh, S. C., \& Hsieh, C. F. (1990). The use of organic matter in crop production food and fertilizer technology center, extention bulletin No. 315 November 1990. Republic of China of Taiwan.

Hudson, B. (1994). Soil organic matter and water holding capacity. J. Soil Water Conserv, 49, 189-194.

Isaac, L., Wood, C. W., \& Shannon, D. A. (2003). Pruning management effects on soil carbon and nitrogen in contour-hedgerow cropping with Leucaena leucocephala (Lam.) De Wit on sloping land in Haiti. Nutrient Cycling in Agroecosystems, 65(3), 253-263.
Jackson, M. L. (1973). Soil Chemical Analysis (1 $1^{\text {st }}$ Ed), Prentice Hall of India Private Limited, New Delhi, 111-204.

Jeyamala, M., \& Soman P. (1999). Short term changes in soil fertility status in intensively managed Teak plantation. Indian Journal of Forestry, 22, 106-111.

JI, S. N., \& Under, P. W. (2001). Soil water accumulation under different precipitation, potential evaporation and straw mulch conditions. Soil Science Society of America Journal, 65, 442-448.

Kang, B. T. (1997). Alley cropping-soil productivity and nutrient recycling. Forest Ecology and Management, 91(1), 75-82.

Kay, B. D. (2018). Soil structure and organic carbon: a review. Soil processes and the carbon cycle, 169-197.

Kimaro, A. A., Timmer, V. R., Mugasha, A. G., Chamshama, S. A., \& Kimaro, D. A. (2007). Nutrient use efficiency and biomass production of tree species for rotational woodlot systems in semi-arid Morogoro, Tanzania. Agroforestry Systems, 71(3), 175-184.

Kuchenbuch, R. O., \& Ingram, K. T. (2004). Effects of soil bulk density on seminal and lateral roots of young maize plants (Zea mays L.). Journal of Plant Nutrition and Soil Science, 167(2), 229-235.

Latt, C. R., Nair, P. K. R., \& Kang, B. T. (2000). Interactions among cutting frequency, reserve carbohydrates, and post-cutting biomass production in Gliricidia sepium and Leucaena leucocephala. Agroforestry Systems, 50(1), 27-46.

Lin, C., Tu, S., Huang, J., \& Chen, Y. (2009). The effect of plant hedgerows on the spatial 
distribution of soil erosion and soil fertility on sloping farmland in the purple-soil area of China. Soil and Tillage Research, 105(2), 307-312.

Liyanage, M. D. S. and Dassanayake, KB 1993. Experiences in coconut based farming systems in Sri Lanka. Advances in Coconut Research and Development, 357-368.

Mahindapala, R. 1989. Coconut Research Institute of Sri Lanka Report. CRB, Sri Lanka.

Manivannan, S., Balamurugan, M., Parthasarathi, K., Gunasekaran, G., \& Ranganathan, L. S. (2009). Effect of vermicompost on soil fertility and crop productivitybeans (Phaseolus vulgaris). Journal of environmental biology, 30(2), 275-281.

Mapa, R. B., \& Dassanayake, A. R. (2005). Soils of the Intermediate zone of Sri Lanka: morphology, characterization and classification.

McDaniel, M. D., Tiemann, L. K., \& Grandy, A. S. (2014). Does agricultural crop diversity enhance soil microbial biomass and organic matter dynamics? A meta-analysis. Ecological Applications, 24(3), 560-570.

Moore, E. B., Wiedenhoeft, M. H., Kaspar, T. C., \& Cambardella, C. A. (2014). Rye cover crop effects on soil quality in no-till corn silagesoybean cropping systems. Soil Science Society of America Journal, 78(3), 968-976.

Masiunas, J. B. (1998). Production of vegetables using cover crop and living mulches-a review. Journal of Vegetable Crop Production, 4(1), 11-31.

Nair, P. R., Buresh, R. J., Mugendi, D. N., \& Latt, C. R. (1999). Nutrient cycling in tropical agroforestry systems: myths and science.
Agro Forestry in Sustainable Agricultural Systems. CRC Press, Boca Raton, FL, USA.

Nziguheba, G., Merckx, R., Palm, C. A., \& Rao, M. R. (2000). Organic residues affect phosphorus availability and maize yields in a Nitisol of western Kenya. Biology and Fertility of Soils, 32(4), 328-339.

Poeplau, C., \& Don, A. (2015). Carbon sequestration in agricultural soils via cultivation of cover crops-A meta-analysis. Agriculture, Ecosystems \& Environment, 200, 33-41.

Quinkenstein, A., Woellecke, J., Böhm, C., Grünewald, H., Freese, D., Schneider, B. U., \& Hüttl, R. F. (2009). Ecological benefits of the alley cropping agroforestry system in sensitive regions of Europe. Environmental Science \& Policy, 12(8), 1112-1121.

Reddy, K. S., Mohanty, M., Rao, D. L. N., Singh, M., Dalal, R. C., Rao, A. S., ... \& Menzies, N. E. A. L. (2008). Nitrogen mineralization in a Vertisol from organic manures, green manures and crop residues in relation to their quality. Agrochimica, 52(6), 377-388.

Sangakkara, U. R., Liedgens, M., Soldati, A., \& Stamp, P. (2004). Root and shoot growth of maize (Zea mays) as affected by incorporation of Crotalaria juncea and Tithonia diversifolia as green manures. Journal of Agronomy and Crop Science, 190(5), 339-346.

Schjønning, P., Elmholt, S., \& Christensen, B. T. (2004). Soil quality management Concepts and terms. In: Managing soil quality: Challenges in modern Agriculture. CABI, Wallingford, U.K, 1-16.

Seiter, S., \& Horwath, W. R. (2004). Strategies for managing soil organic matter to supply 
plant nutrients. Soil organic matter in sustainable agriculture. CRC Press, Boca Raton, FL, 269-293.

Senarathne, S. H., \& Sangakkara, R. U. (2009). Effect of different weed management systems on the weed populations, and seedbank composition and distribution in tropical coconut plantations. Weed biology and management, 9(3), 209-216.

Senarathne, S. H. S., Samarajeewa, A. D., \& Perera, K. C. P. (2003). Comparison of different weed management systems and their effects on yield of coconut plantations in Sri Lanka. Weed Biology and Management, 3(3), 158-161.

Sileshi, G., \& Mafongoya, P. L. (2006). Long-term effects of improved legume fallows on soil invertebrate macrofauna and maize yield in eastern Zambia. Agriculture, Ecosystems \& Environment, 115(1-4), 69-78.

Silva, G. T. A., Matos, L. V., Nóbrega, P. D. O., Carneiro, E. F., \& Resende, A. S. D. (2008). Chemical composition and decomposition rate of plants used as green manure. Scientia Agricola, 65(3), 298-305.

Simard, R. R. (1993). Ammonium acetate extractable elements In: Soil sampling and methods of analysis. Eds: Martin. R and Carter. S.

Six, J., Conant, R. T., Paul, E. A., \& Paustian, K. (2002). Stabilization mechanisms of soil organic matter: implications for C-saturation of soils. Plant and soil, 241(2), 155-176.

Velayutham, M. (2011). Livelihood impacts of soil health improvement in backward and tribal districts of Andhra Pradesh. Indian Journal of Dryland Agricultural Research and Development, 26(1), 119-119.
Statistical Analysis Systems [SAS]. (1999). SAS 1, STAT Users Guide, Release, 7.00 Cary, NC: Statistical Analysis Systems Institute, 1028.

Steele, M. K., Coale, F. J., \& Hill, R. L. (2012). Winter annual cover crop impacts on notill soil physical properties and organic matter. Soil Science Society of America Journal, 76(6), 2164-2173.

Steenwerth, K., \& Belina, K. M. (2008). Cover crops enhance soil organic matter, carbon dynamics and microbiological function in a vineyard agroecosystem. Applied soil ecology, 40(2), 359-369.

Stotzky, L. M. (1965). Chemical and microbiological properties. In: Black, C. A. E. White, J. L., Ensminger, L. E., \& Clarke, F. E., ed. Methods of soil analysis. Madison, Soil Science Society of America, 2, 1550-1572.

Villamil, M. B., Bollero, G. A., Darmody, R. G., Simmons, F. W., \& Bullock, D. G. (2006). Notill corn/soybean systems including winter cover crops: Effects on soil properties. Soil Science Society of America Journal, 70(6), 1936-1944.

Walkley, A., \& Black, I. A. (1934). An examination of the Degtjareff method for determining soil organic matter, and a proposed modification of the chromic acid titration method. Soil science, 37(1), 29-38.

Wang, L., Tang, L., Wang, X., \& Chen, F. (2010). Effects of alley crop planting on soil and nutrient losses in the citrus orchards of the Three Gorges Region. Soil and Tillage Research, 110(2), 243-250.

Young, A. (1997). Agroforestry for soil management (No. Ed. 2). CAB international. 